\title{
EKSISTENSI PARTAI POLITIK DI INDONESIA MASA PRA DAN PASCA KEMERDEKAAN
}

\author{
Nadhifatus Shofia ${ }^{1}$, Moch. Zaidan Alamsyafi ${ }^{2}$ \\ ${ }^{12}$ Universitas Islam Negeri Sunan Ampel Surabaya \\ 1nadhifa.shofia07@gmail.com, ${ }^{2}$ zaidanalamsyafi01@gmail.com
}

\begin{abstract}
The political system in Indonesia always has a close relationship with political parties. Basically, the emergence of political parties is the actualization of the various sects or political views that lie behind them. Through a theoretical and law approach, this paper discusses the existence of political parties in Indonesia, especially in the pre and post independence period. The author concludes that in terms of basic ideological aspects, the emergence of Indonesian political parties in the pre-independence era is the actualization of three political streams or views that found momentum in the 20th century. The three streams referred to are Nationalism, Islam, and Marxism/Socialism. After the proclamation of independence, the emergence of the concept of multiple parties gave rise to several new political parties. The formation of political parties after the proclamation of independence is often based on the values or principles of divinity, nationality, and Marxism. However, this does not prevent the emergence of parties that were born based on values or other principles.
\end{abstract}

\section{Keywords: Political Parties, Interests, Ideologies.}

\begin{abstract}
ABSTRAK
Sistem politik di Indonesia selalu memiliki keterkaitan erat dengan partai politik. Pada dasarnya munculnya partai politik merupakan aktualisasi dari beragam aliran atau pandangan politik yang melatarbelakanginya. Melalui pendekatan teori dan perundang-undangan, tulisan ini membahas eksistensi partai politik di Indonesia, terutama pada masa pra dan pasca kemerdekaan. Penulis menyimpulkan bahwa ditinjau dari aspek ideologi dasar, secara garis besar lahirnya partai politik di Indonesia pada masa pra kemerdekaan merupakan aktualisasi dari tiga aliran atau pandangan politik yang menemukan momentumnya pada abad ke-20. Ketiga aliran yang dimaksud adalah Nasionalisme, Islam, dan Marxisme/Sosialisme. Pasca proklamasi kemerdekaan, munculnya konsep banyak partai (multy party) melahirkan beberapa partai politik baru. Uniknya, sebagian besar partai-partai tersebut belum sepenuhnya bisa melepaskan diri dari kondisi sebelumnya. Lahirnya partai politik merupakan aktualisasi dari tiga aliran atau pandangan politik pada masa pra kemerdekaan. Pembentukan partai politik setelah Indonesia merdeka kerap didasarkan pada nilai atau prinsip ketuhanan, kebangsaan, dan marxisme. Meskipun demikian, hal ini tidak lantas menghalangi kemunculan partai-partai yang lahir dengan berlandaskan nilai atau prinsip lainnya.
\end{abstract}

Kata Kunci: Partai Politik, Kepentingan, Ideologi. 


\section{PENDAHULUAN}

Indonesia merupakan negara hukum berbentuk kesatuan dengan pemerintahan berbentuk republik dan sistem pemerintahan presidensial bercorak parlementer. Indonesia tidak menganut sistem pemisahan kekuasaan, melainkan pembagian kekuasaan. Meskipun sebagian besar penduduk Indonesia beragama Islam, tetapi Indonesia bukan negara Islam. Lembaga eksekutif dipimpin oleh presiden yang merangkap sebagai kepala negara dan kepala pemerintahan. Dalam menjalankan tugasnya, presiden dibantu oleh wakil presiden selaku pembantu presiden yang berkedudukan di atas menteri. Lembaga legislatif terbagi menjadi dua kamar dalam Majelis Permusyawaratan Rakyat (MPR), yaitu Dewan Perwakilan Rakyat (DPR) dan Dewan Perwakilan Daerah (DPD). Lembaga yudikatif selaku pemegang kekuasaan kehakiman terdiri atas Mahkamah Agung (MA) dan Mahkamah Konstitusi (MK). Adapun lembaga inspektif berada dalam kendali Badan Pemeriksa Keuangan (BPK) dengan perwakilan di masing-masing provinsi dan kabupaten/kota di seluruh Indonesia.

Indonesia terdiri atas 34 provinsi. 5 di antaranya mengantongi status otonomi yang berbeda. Status Daerah Otonomi Khusus melekat pada 3 daerah, yakni Papua, Aceh, dan Papua Barat; Status Daerah Istimewa melekat pada 1 daerah, yakni Yogyakarta; serta status Daerah Khusus Ibu Kota melekat pada 1 daerah, yakni Jakarta. Masing-masing provinsi terbagi menjadi kota/kabupaten, di mana masing-masing kota/kabupaten terbagi lagi menjadi kecamatan/distrik yang selanjutnya terbagi lagi menjadi kelurahan/desa hingga terakhir adalah rukun tetangga. Pemilihan Umum diselenggarakan setiap 5 tahun sekali untuk memilih anggota DPR, DPD, serta DPRD yang disebut pemilihan umum legislatif (Pileg) dan pemilihan umum presiden (Pilpres) yang diselenggarakan untuk memilih Presiden dan Wakil Presiden. Dalam konteks Indonesia, Pemilihan Umum menganut sistem multipartai.

Bila diperhatikan, terdapat perbedaan mendasar antara sistem politik Indonesia dengan sistem politik negara-negara demokratis lainnya. Di antara perbedaan yang dimaksud yaitu Majelis Permusyawaratan Rakyat yang merepresentasikan karakter Indonesia, Mahkamah Konstitusi (MK) yang memiliki wewenang mengadili sengketa hasil Pemilihan Umum (Pemilu), bentuk negara 
kesatuan yang menggunakan prinsip-prinsip federalisme semisal keberadaan Dewan Perwakilan Daerah (DPD), dan sistem multipartai di mana partai politik peserta Pemilihan Umum (Pemilu) dituntut untuk memenuhi ambang batas sekian persen agar bisa menjadikan kadernya sebagai anggota Dewan Perwakilan Rakyat (DPR) atau anggota Dewan Perwakilan Rakyat Daerah (DPRD).

Sistem politik di Indonesia selalu memiliki keterkaitan dengan partai politik. Itulah mengapa, eksistensi partai politik di Indonesia selalu menarik untuk dicermati. Pada masa belakangan atau pasca reformasi, munculnya partai politik merupakan aktualisasi dari beragam aliran atau pandangan politik yang melatarbelakanginya. Pintu demokrasi terbuka semakin lebar seiring dengan tumbangnya rezim pemerintahan Orde Baru. Berbagai kelompok dalam masyarakat akhirnya memilih untuk menyuarakan aspirasi dan kepentingannya melalui partai politik. Bila diperhatikan, kondisi demikian sebenarnya tidak jauh berbeda dengan masa-masa sebelumnya, di mana aktualisasi dari sejumlah aliran atau pandangan politik turut membentuk lahirnya partai politik. Bertujuan agar artikel ini memiliki fokus kajian, penulis memilih untuk membahas keberadaan partai politik di Indonesia pada masa pra dan pasca kemerdekaan.

\section{METODE PENELITIAN}

Metode yang digunakan dalam peneltiian ini adalah mengikuti metode penelitian hukum normatif. Pendekatan penelitian berdasarkan pemilihan metode penelitian hukum Normatif, sehingga penelitian ini menggunakan pendekatan teori dan perundang-undangan, tulisan ini membahas eksistensi partai politik di Indonesia, terutama pada masa pra dan pasca kemerdekaan. Kemudian menganalisis dengan mengutip pasal-pasal yang berisi norma-norma hukum yang ada relevansinya dengan pokok permasalahan, sehingga di peroleh jawaban terhadap permasalahan yang dikemukakan.

\section{HASIL DAN PEMBAHASAN}

\section{Terminologi Partai Politik}

Partai politik merupakan pencerminan negara demokratis yang dianggap menjadi prasyarat kehidupan negara modern.Partai politk merupakan lembaga penyalur kepentingan penguasa dan rakyat sekaligus. Posisi ini menjadikan partai politik selaku sarana komunikasi dua arah, yaitu dari bawah ke atas dan sebaliknya. 
Apabila posisi demikian berhasil diimplementasikan, maka fungsi partai politik dalam melaksanakan partisipasi politik, sosialisasi politik, komunikasi politik, agregasi kepentingan, artikulasi kepentingan, serta melahirkan bermacam kebijakan bisa berjalan secara optimal. Hal ini mengakibatkan terwujudnya pembangunan politik yang diharapkan. ${ }^{1}$

Partai poliltik merupakan komponen vital dalam dinamika perpolitikan sebuah bangsa.Partai politik dipercaya menjadi cara individu atau kelompok guna meraih kekuasaan.Secara etimologi, politik berasal dari kata polis (Yunani) yang bermakna kota atau negara kota. Kata ini menurunkan polities yang bermakna warga negara, politike te ckne bermakna kemahiran politik dan politike episteme yang bermakna ilmu politik.Secara istilah, politik memuat upaya mencapai sekaligus mewujudkan cita-cita atau idiologi.

Filusuf yang memperkenalkan kata politik pertama kali yaitu Aristoteles dengan mengatakan "manusia pada dasarnya adalah binatang politik". Berdasarkan penjelasannya, hakikat kehidupan sosial sebenarnya merupakan politik dan interaksi satu sama lain dari dua atau lebih orang yang melibatkan hubungan politik. Menurut arti yang lebih luas, semua orang merupakan politisi. Dalam konteks ini, Aristoteles berpandangan bahwa satu-satunya cara mengoptimalkan potensi individu sekaligus mewujudkan kehidupan sosial tertinggi yaitu melalui interaksi politik dengan orang lain dalam kerangka kelembagaan, yang didesain guna mengatasi konflik sosial sekaligus mewujudkan tujuan kolektif bernegara. Atas dasar itulah, setiap orang merupakan politisi, walaupun sebagian penjabat negara lebih sering melakukan aktivitas politik ketimbang warga negara lainnya. ${ }^{2}$

Secara umum bisa dikatakan bahwa partai politik adalah kelompok terorganisir yang anggota-anggotanya memiliki nilai, orientasi, serta cita-cita yang sama. Miriam Budiardjo, mengutip pandangan Carl J. Friedrich, mengatakan bahwa partai politik merupakan sekelompok manusia terorganisir dengan tujuan merebut atau mempertahankan penguasaan terhadap pemerintahan bagi pimpinan partainya dan berdasarkan penguasaan tersebut memberikan kemanfaatan idiil dan materiil kepada anggotanya. Tujuan kelompok ini yaitu memperoleh kekuasaan politik dan

\footnotetext{
1 Tulus Warsito, Pembangunan Poltik Refleksi Kritis atas Krisis, Bigraf Publishing, Yogyakarta, 1999, h. 94.

${ }^{2}$ Ibid., 95.
} 
merebut kedudukan politik secara konstitusional guna mewujudkan kebijakankebijakan mereka.

Merujuk Sigmund Neumann, partai politik adalah organisasi para aktivis politik yang berupaya mengendalikan kekuasaan pemerintahan serta menarik dukungan rakyat berdasarkan rivalitas dengan sejumlah golongan dengan pandangan berlainan. Batasan partai politik yang digariskan RH Soltau dalam An Introduction to Politics ternyata sama dengan apa yang ditulis oleh Raymond Garfield Gettel dalam Political Science.Dengan demikian, partai politik secara umum adalah organisasi yang berusaha untuk memperoleh serta menggunakan kekuasaan. Mengacu beberapa terminologi partai politik, dapat diambil kesimpulan bahwa partai politik merupakan hasil pengorganisasian dari sekelompok orang agar memperoleh kekuasaan untuk menjalankan program yang telah direncanakan. ${ }^{3}$

\section{Fungsi Partai Politik}

Beberapa fungsi partai politik sebagai berikut:

1. Menyelenggarakan pendidikan politik bagi masyarakat supaya menjadi warga negara yang sadar mengenai hak dan kewajibannya dalam kehidupan bermasyarakat, berbangsa, dan bernegara.

2. Menciptakan iklim kondusif bagi persatuan dan kesatuan bangsa Indonesia guna menyejahterakan masyarakat.

3. Menyerap, menghimpun, serta menyalurkan aspirasi politik masyarakat dalam rangka merumuskan kebijakan negara.

4. Melaksanakan partisipasi politik bagi warga negara Indonesia.

5. Melakukan rekrutmen politik melalui mekanisme demokrasi untuk mengisi jabatan politik dengan mempertimbangkan kesetaraan gender. ${ }^{4}$

Muncul pandangan yang berbeda tentang partai politik di negara demokratis dan negara otoriter. Pada umumnya perbedaan pandangan ini berimbas pada pelaksanaan tugas atau fungsi partai di masing-masing negara. Di negara demokratis, partai relatif mampu menjalankan fungsi sesuai kadarnya pada waktu kelahirannya, yakni menjadi wadah bagi warga negara untuk ikut serta dalam kehidupan bernegara sekaligus menyuarakan kepentingannya. Sementara di negara otoriter, selain kesulitan menunjukkan kualitasnya, partai juga lebih kerap menjalankan kehendak penguasa. Berikut fungsi partai politik di negara demokrasi dan negara otoriter.

\footnotetext{
${ }^{3}$ Ibid., 96.

${ }^{4}$ Wakhidatul Afifah, Implementasi Fungsi Partai Politik, Mustika Cemerlang, Semarang 2011, h. 17
} 


\section{Fungsi di Negara Demokrasi}

\section{Sebagai sarana komunikasi politik}

Partai politik menggabungkan kepentingan berupa pendapat dan inspirasi, mengolah, serta merumuskannya dalam bentuk yang lebih teratur. Proses ini biasanya dinamakan perumusan kepentingan. Jika hal tersebut tidak dilakukan, maka aspirasi dalam partai politik akan berjalan simpang siur dan saling bertabrakan. Atas dasar inilah, melalui penghimpunan atau artikulasi inilah, benturan kepentingan dan kesimpangsiuran bisa ditekan.

Melalui lembaga legislatif, partai politik selanjutnya dapat merumuskan beberapa usulan yang bisa ditetapkan dalam platform atau program partai politik untuk dikemukakan kepada pemerintah. Langkah ini dilakukan supaya rumusan tersebut menjadi kebijakan umum. Melalui partai politik, tuntutan dan kepentingan masyarakat akhirnya bisa disampaikan kepada pemerintah.

\section{$\underline{\text { Sebagai sarana sosialisasi atau pendidikan politik }}$}

Sosialisasi politik merupakan proses yang dilalui oleh individu untuk mendapatkan sikap dan orientasi terhadap fenomena politik. Pada umumnya proses ini berlaku dalam suatu masyarakat di mana ia tinggal. Sosialisasi politik menjadi bagian dari proses yang kerap menentukan sikap politik seseorang, semisal kelas sosial, suku bangsa, nasionalisme, ideologi, hak dan kewajiban.

Sebagai sarana rekruitmen politik

Fungsi ini berhubungan erat dengan seleksi kepemimpinan internal partai dan kepemimpinan nasional. Untuk kepentingan internal, setiap partai tentu membutuhkan kader-kader berkualitas. Tersedianya kader-kader bermutu menyebabkan partai politik memiliki peluang lebih besar untuk maju dan berkembang. Dalam kondisi demikian, selain mudah menentukan pemimpin internal, partai politik juga berpeluang untuk mengajukan sebagian kadernya dalam bursa kepemimpinan nasional.

\section{$\underline{\text { Sebagai sarana pengatur konflik }}$}

Konflik akan selalu muncul dalam kehidupan masyarakat, terlebih apabila masyarakatnya bercorak heterogen. Lahirnya konflik bisa ditinjau dari segi etnis, sosial dan ekonomi, serta agama. Hal ini dikarenakan masing-masing perbedaan rentan mengundang potensi konflik. Dalam konteks inilah, peran partai politik 
sangat dibutuhkan guna mengatasi konflik atau sekurangnya mengatur sedemikian rupa agar ekses negatifnya bisa ditekan secara maksimal. Elite partai politik bisa saling menumbuhkan pengertian di antara mereka sekaligus merawat kepercayaan para pendukungnya. ${ }^{5}$

\section{Fungsi di Negara Otoriter}

Salah satu contoh fungsi partai politik di negara otoriter yang dapat kita lihat yaitu di Uni Soviet. Menurut paham komunis disana, sifat dan tujuan partai politik bergantung pada situasi apakah partai komunis berkuasa dinegara dimana ia berada atau tidak. Di negara di mana partai komunis tidak berkuasa, partai-partai politik lain dianggap sebagai mewakili kepentingan kelas tertentu yang tidak dapat bekerja untuk kepentingan umum. Maka dari itu, partai ini menjadi paling efektif di negara yang pemerintahannya lemah dan yang rakyatnya kurang bersatu. ${ }^{6}$

\section{Pendirian Partai Politik di Indonesia}

Menurut teori ilmu poltik, partai politik adalah alat yang dirancang oleh manusia dan dianggap paling ampuh untuk mewujudkan tujuan politiknya. Mengingat urgensi partai politik, tak heran apabila muncul pameo "politisi modern tanpa partai politik sama saja dengan ikan yang berada di luar air". Sebagai institusi, partai politik memiliki keterkaitan erat dengan masyarakat dalam upaya mengendalikan kekuasaan. Keterkaitan tesebut seringkali mendapat pengaruh dari kebudayaan masyarakat yang telah membentuknya. Apabila lahirnya partai politik merupakan pengejewantahan dari kedaulatan rakyat, maka semangat kebebasan dianggap selaku pengendali kekuasaan.

Partai politik sering dianggap sebagai salah satu atribut negara demokrasi modern. Tak ada seorang ahli pun menyangkal persepsi tersebut. Mengingat, negara-negara yang memiliki kedaulatan membutuhkan kehadiran partai politik. Bagi negara-negara yang merdeka, eksistensi partai politik merupakan prasyarat untuk menyalurkan aspirasi rakyat serta melibatkan mereka secara langsung dalam menyelenggarakan negara melalui badan perwakilannya. ${ }^{7}$

\footnotetext{
${ }^{5}$ Miriam Budiardjo, Dasar-dasar Ilmu Politik, Gramedia Pustaka Utama, Jakarta, 2007, h. 409.

${ }^{6}$ Ibid., h. 412.

Asep Mulyana, "Perkembangan Pemikiran HAM", https://referensi.elsam.or.id/2015/01/perkembangan-pemikiran-ham/.
} 
Partai politik kerap diasosiasikan menjadi organisasi perjuangan individu atau kelompok untuk mencari sekaligus memperjuangkan kedudukan politiknya dalam negara. Tidak selalu memakai kekerasan atau kekuatan fisik, bentuk perjuangan partai politik bisa juga melalui beragam konflik dan rivalitas internal maupun antar partai yang telah melembaga.

Sebagaimana pendapat Stevenson dan Huszar dalam karyanya berjudul Political Science "Partai Politik ialah sekelompok orang yang terorganisir serta berusaha untuk mengendalikan pemerintahan agar supaya dapat melaksanakan progam-progamnya dan menempatkan/menundukkan anggota-anggotanya dalam jabatan pemerintah; partai politik berusaha untuk memperoleh kekuasaan dengan dua cara yaitu ikut serta dalam pelaksanaan pemerintah secara sah,dengan tujuan bahwa dalam pemilu memperoleh suara mayoritas dalam badan legislatif,atau mungkin bekerja secara tidak sah/subversif untuk memperoleh kekuasaan tertinggi dalam negara yaitu melalui revolusi atau coup d'etat."

Rivalitas partai politik merupakan bagian intergral dalam proses politik, guna meraih kemenangan dalam Pemilu. Dengan meraih suara terbanyak dalam pemilu, partai bersangkutan tentu lebih mudah mengendalikan negara dan pemerintahan; mengukuhkan sekaligus memperjuangkan ideologinya; mempertahankan posisi elit politik dalam kekuasaan; serta mewujudkan tujuan yang lebih lanjut, yaitu melakukan pengawasan terhadap kebijaksanaan umum. Sebagaimana Carl. J. Friederich yang berpandangan bahwa partai poltik merupakan sekelompok manusia yang terorganisir yang bertujuan untuk mepertahankan pemimpin-pemimpinnya, mengendalikan pemerintahan dan bahkan menjamin keuntungan material maupun spiritual kepada anggota partai.

Sejarah mencatat bahwa untuk pertama kalinya berkembangnya partai politik di negara-negara Eropa Barat menjadi tahap agar pemerintahan mestinya berlandaskan kontitusi dan lembaga perwakilan. Pembangunan politik di sana dianggap mengekang monarchi absolut sekaligus memperluas hak-hak seseorang sebagai warga negara. Rupanya keberhasilan tersebut mendorong meluasnya wacana bahwa rakyat seharusnya selalu diperhitungkan serta diikutsertakan dalam proses politik. Partai politik dalam perjalanannya berfungsi menjadi penghubung antara rakyat dengan pemerintahan. Dengan demikian, rakyat bisa secara leluasa 
menentukan pilihan, menyuarakan kepentingan, mengkritik rezim pemerintahan, melakukan tata hubungan politik dan lain sebagainya.

Telah muncul beberapa penelitian empiris yang menunjukkan perspektif baru. Penelitian yang dimaksud menunjukkan bahwa partai politik beserta sistem kepartaian yang dipakai dapat dianalisis sekaligus dipahami secara lebih intens dalam dalam kehidupan masa kini. Di samping itu, bermacam upaya ditempuh guna mengaitkan partai politik dengan lembaga lainnya yang ada dalam suatu masyarakat, dengan bermacam kelompok dengan maksud memperoleh kursi kekuasaan beserta perwujudan kepentingannya. ${ }^{8}$

Masyarakat dalam konteks ini kerap dinilai selaku organisme dinamis. Beragam rivalitas guna memperoleh prestis, status, kekuasaan, dan perasaan aman dapat berkembang di dalamnya. Biasanya rivalitas diselimuti dengan tujuan-tujuan yang ingin diwujudkan. Bahkan, ada kalanya rivalitas ini ditunjukkan dengan menampilkan atribut-atribut kelompok yang berafiliasi agar kepentingannya bisa diperjuangkan. Konflik dan rivalitas seperti ini tak mungkin terelakkan dalam kehidupan sehari-hari. Banyak penelitian empiris menggambarkan adanya perspektif baru di mana analisis dan pemahaman terhadap partai politik bisa dilakukan secara lebih mendalam.Menurut apa yang digariskan melalui UUD 1945, sebenarnya kata-kata "partai politik" tak dijumpai. Hal ini bukan berarti bahwa partai politik tidak diatur, apalagi apabila menyangkut kepentingan bangsa dan negara. Perkembangan demokrasi di Indonesia dalam kaitannya dengan implementasi UUD 1945, Konsitusi RIS dan UUDS 1950, menunjukkan adanya kecenderungan untuk mengatur kehidupan partai politik.

Ditinjau dari aspek ideologi dasar, secara garis besar lahirnya partai politik di Indonesia pada masa pra kemerdekaan merupakan aktualisasi dari tiga aliran atau pandangan politik yang menemukan momentumnya pada abad ke-20. Ketiga aliran yang dimaksud adalah Nasionalisme, Islam, dan Marxisme/Sosialisme. Aktualisasi aliran Islam muncul pertama kali dalam Sarekat Islam (SI), selaku partai politik paling awal yang bersifat nasional. Kerap dinilai sebagai pelopor, partai ini cukup dinamis saat dipimpin oleh H. O. S. Cokroaminoto. Apa yang menarik dari SI periode awal yaitu keberhasilannya mengidentitaskan diri dengan aspirasi politik

\footnotetext{
${ }^{8}$ Ibid.
} 
Bumi Putera dalam menyuarakan kemerdekaan. Munculnya PKI dan PNI yang bercorak ideologi Marxisme dan Nasionalisme pada tahun 1920-an ternyata berimbas pada merosotnya wibawa SI. Akibatnya, partai ini tidak mampu bersaing dengan sejumlah ideologi Barat yang modern, terutama dalam menarik simpati massa. $^{9}$

Dalam tempo yang relatif singkat, PKI yang lahir pada 1920 mampu berkembang cukup pesat dalam bidang organisasi dan upaya menyebarluaskan Marxisme/Komunisme. Tak hanya berhasil merebut massa, PKI juga mampu menarik simpati para intelektual, terlebih dengan mengenalkan analisa Lenin dan Bucharin mengenai imperalisme sebagai level terakhir kapitalisme. Apabila pemberontakan PKI tahun 1926/1927 tidak meletus, bisa jadi PKI bakal menjadi pelopor penentang kolonialisme atau imperalisme. Pada saat itu, kesalahan PKI yaitu menginisiasi "pemberontakan" tanpa adanya persiapan yang cukup matang. Pada 1927 hingga 1945, aktualisasi ideologi Marxis lenyap dari gerakan politik Indonesia. Posisinya akhirnya tergantikan oleh PNI selaku partai radikalrevolusioner, di mana Soekarno mampu belajar dari kesalahan PKI dan SI. ${ }^{10}$

Jalan pemikiran yang mendasari organisasi-organisasi politik semisal SI, PKI, PNI, PSII, Partindo, Parindra, serta beberapa kelompok yang dibentuk berdasarkan suku kedaerahan semisal Sarikat Sumatra, Paguyuban Pasundan, Rukun Minahasa, Serikat Ambon, Kaum Betawi, dan lain sebagainya secara sepintas adalah memperjuangkan kemerdekaan. Namun demikian, kalau diklasifikasi lebih lanjut, tampak berbagai alasan dari aliran politik Nasionalisme, Islam, dan Marxisme dalam menuntut kemerdekaan.

Partai politik di Indonesia seringkali disibukkan dengan bermacam masalah, semisal cara mengorganisir diri agar terhindar dari perpecahan; cara merawat hubungan antara partai politik dengan pendukungnya; cara ideologi berperan mendapatkan sarana materiil; serta cara mengupayakan berputarnya mesin partai. Perpecahan dalam partai politik, menurut Ahmad Syafe'i Ma'arif, sebenarnya tidak disulut oleh perbedaan penafsiran terhadap ideologi, melainkan karena perbedaan pandangan dalam menjadikan ideologi partai politik lebih aktual. Hal ini melibatkan sikap partai politik terhadap pemerintah Hindia Belanda. Misalnya

\footnotetext{
${ }^{9}$ Ibid.

${ }^{10}$ Ibid.
} 
perubahan sikap dari non-kooperatif menjadi kooperatif. Setelah PNI dibubarkan hingga kemunculan Jepang pada 1942, tak ada ideologi yang cukup dominan dalam pergerakan politik Indonesia. Adapun pada masa kolonialisme Jepang (1942-1945), semua kegiatan partai politik di Indonesia ternyata dihentikan.

Pasca proklamasi kemerdekaan, tepatnya mulai 30 Oktober 1945, BP-KNIP berfungsi selaku parlemen sementara sebelum diselenggarakannya pemilu. Badan ini berwenang membentuk partai politik dengan konsep banyak partai (multy party). Hal ini berdasarkan pertimbangan bahwa "berbagai pendapat yang ada di dalam masyarakat akan tersalur secara tertib". Apa yang menjadi dasar pertimbangan lainnya yaitu "bahwa partai politik akan memperkokoh perjuangan mempertahankan kemerdekaan dan pemeliharaan keamanan masyarakat”.

Terbitnya Maklumat Pemerintah 3 November 1945 yang ditandatangani oleh Moh. Hatta selaku Wakil Presiden mengukuhkan keberadaan partai politik di Indonesia. Maklumat tersebut di antaranya berisi kemauan pemerintah tentang kehadiran partai politik di Indonesia. Keberadaan partai politik menjadikan bermacam paham dalam masyarakat bisa tersalurkan dengan baik. Di samping itu, terdapat batas waktu pendirian partai politik. Sebelum pemilihan badan perwakilan rakyat diselenggarakan pada Januari 1946, muncul tuntutan agar kepengurusan partai politik tersusun terlebih dahulu. Dengan maklumat pemerintah tersebut, selain pembentukan partai politik pada zaman penjajahan Belanda dan Jepang, lahirlah sejumlah partai politik baru. ${ }^{11}$

Berdasarkan buku Kepartaian Indonesia yang dikeluarkan oleh Kementrian Penerangan pada tahun 1951, partai politik yang telah ada sejak terbitnya Maklumat Pemerintah di atas digolongkan sebagai berikut ${ }^{12}$ :

\begin{tabular}{|l|lr|c|c|}
\hline Dasar Ketuhanan & \multicolumn{2}{|c|}{ Dasar Kebangsaan } & Dasar Marxisme & Partai lain-lain \\
\hline a) Masjumi; & a) Partai Nasional & a) Partai Komunis & a)Partai \\
b) Partai Sjarikat & \multicolumn{2}{|c|}{ Indonesia (PNI); } & Indonesia (PKI); & Demokrat \\
Indonesia; & b) Persatuan & b) Partai Sosialis & Tionghoa \\
c) Pergerakan & \multicolumn{2}{|c|}{ Indonesia Raya } & Indonesia; & (PTDI); \\
Tarbiah & (PIR); & c) Partai Murba; & b)Partai \\
\hline
\end{tabular}

11 Ibid.

${ }^{12}$ Ibid. 


\begin{tabular}{|c|c|c|c|}
\hline $\begin{array}{l}\text { Islamiah; } \\
\text { d) Partai Kristen } \\
\text { Indonesia; } \\
\text { e) Partai Katholik }\end{array}$ & $\begin{array}{l}\text { c) Partai Indonesia } \\
\text { Raya (Parindra); } \\
\text { d) Partai Rakyat } \\
\text { Indonesia(PRI); } \\
\text { e) Partai Demokrasi } \\
\text { Rakyat (Banteng); } \\
\text { f)Partai Rakyat } \\
\text { Nasional (PRN); } \\
\text { g) Partai Wanita } \\
\text { Rakyat (PWR); } \\
\text { h) Partai Kebangsaan } \\
\text { Idonesia (Parki); } \\
\text { i)Partai Kedaulatan } \\
\text { Rakya (PKR); } \\
\text { j)Serikat Kerakyatan } \\
\text { Indonesia (SKI); } \\
\text { IkatanNasional } \\
\text { k) Indonesia (INI); } \\
\text { m) Partai Partai Rakyat Jelata } \\
\text { (PRJ); } \\
\text { Indonesia (WDI). }\end{array}$ & $\begin{array}{l}\text { d) Partai Buruh; } \\
\text { e) Persatuan } \\
\text { Rakyat Marhaen } \\
\text { Indonesia } \\
\text { (Permai). }\end{array}$ & $\begin{array}{l}\text { Indonesia } \\
\text { Nasional } \\
\text { (PIN). }\end{array}$ \\
\hline
\end{tabular}

\section{Penggabungan dan Pembubaran Partai Politik}

Ada beberapa peraturan perundang-undangan yang mengatur pembubaran partai politik yang terbit sebelum reformasi. Di antaranya Penetapan Presiden Republik Indonesia Nomor 7 tahun 1959 tentang Syarat-Syarat dan Penyederhanaan Kepartaian, Peraturan Presiden Republik Indonesia Nomor 13 Tahun 1960 tentang Pengakuan, Pengawasan dan Pembubaran Partai-Partai. Pasal 9 ayat (1) dan (2) Penetapan Presiden Republik Indonesia Nomor 7 tahun 1959 tentang Syarat-Syarat dan Penyederhanaan Kepartaian mengatur mengenai 
pembubaran partai politik yang menyatakan Pasal 9 ayat (1) bahwa Presiden, sesudah mendengar Mahkamah Agung, dapat melarang dan/atau membubarkan partai yang bertentangan dengan asas dan tujuan negara, programnya bermaksud merombak asas dan tujuan negara, sedang melakukan pemberontakan karena pemimpin-pemimpinnya turut serta dalam pemberontakan-pemberontakan atau telah jelas memberikan bantuan (sedangkan partai itu tidak dengan resmi menjalankan perbuatann-perbuatan anggota itu), danTidak memenuhi syarat-syarat lain yang ditentukan dalam penetapan presiden ini. Selanjutnya Pasal 9 ayat (2) bahwa Partai yang dibubarkan berdasarkan ayat (1) pasal ini, harus dibubarkan dalam waktu selama-lamanya, terhitung mulai tanggal berlakunya keputusan Presiden yang menyatakan pembubaran itu. ${ }^{13}$

Salah satu latar belakang pengaturan tentang penggabungan partai-partai politik adalah banyaknya partai politik pada masa Presiden Soekarno beraliran nasional yang saling berbeda antara satu dengan lainnya. Misalnya Indonesia Raya yang beraliran tradisi Jawa, Masyumi dan NU yang beraliran Islam, PNI dan PRN yang beraliran nasionalis-radikal, PKI yang beraliran komunis, serta PSI yang beraliran sosial-demokrat. ${ }^{14}$ Beberapa partai ternayta memiliki tujuan yang kurang selaras dengan asas dan tujuan negara. Selain itu, penggabungan ini juga bermaksud mempercepat tercapainya tujuan nasional dan cita-cita bangsa sekaligus menyatukan berbagai golongan dengan tujuan yang sama, yakni memperkuat partai politik dalam pendanaan dan kuatnya nilai-nilai Pancasila. Banyak juga ulasan yang menyebutkan bahwa agar penggabungan ini berdasarkan sila-sila Pancasila, seperti partai ketuhanan, partai kemanusiaan, partai persatuan, partai kerakyatan, dan partai keadilan sosial.

\section{KESIMPULAN}

Muncul pandangan yang berbeda tentang partai politik di negara demokratis dan negara otoriter. Pada umumnya perbedaan pandangan ini berimbas pada pelaksanaan tugas atau fungsi partai di masing-masing negara. Di negara demokratis, partai relatif mampu menjalankan fungsinya sebagai wadah bagi warga

\footnotetext{
${ }^{13}$ Findarost Yufan Madakarah, dkk., "Perkembangan Pengaturan Pembubaran Partai Politik dalam Sistem Ketatanegaraan Republik Indonesia", Diponegoro Law Journal, Vol. 6. No. 2. (April 2017), h. 6.

${ }^{14}$ Ibid., h. 8 .
} 
negara untuk ikut serta dalam kehidupan bernegara sekaligus menyuarakan kepentingannya. Sementara di negara otoriter, selain kesulitan menunjukkan kualitasnya, partai juga lebih kerap menjalankan kehendak penguasa.

Ditinjau dari aspek ideologi dasar, secara garis besar lahirnya partai politik di Indonesia pada masa pra kemerdekaan merupakan aktualisasi dari tiga aliran atau pandangan politik yang menemukan momentumnya pada abad ke-20. Ketiga aliran yang dimaksud adalah Nasionalisme, Islam, dan Marxisme/Sosialisme. Aktualisasi aliran Islam muncul pertama kali dalam Sarekat Islam (SI), selaku partai politik paling awal yang bersifat nasional. Munculnya PKI dan PNI yang bercorak ideologi Marxisme dan Nasionalisme pada tahun 1920-an ternyata berimbas pada merosotnya wibawa SI. PKI mampu berkembang cukup pesat dalam bidang organisasi dan upaya menyebarluaskan Marxisme/Komunisme. Tak hanya berhasil merebut massa, PKI juga mampu menarik simpati para intelektual. Pada 1927 hingga 1945, aktualisasi ideologi Marxis lenyap dari gerakan politik Indonesia. Posisinya akhirnya tergantikan oleh PNI selaku partai radikal-revolusioner.

Pasca proklamasi kemerdekaan, munculnya konsep banyak partai (multy party) melahirkan beberapa partai politik baru. Uniknya, sebagian besar partaipartai tersebut belum sepenuhnya bisa melepaskan diri dari kondisi sebelumnya. Lahirnya partai politik merupakan aktualisasi dari tiga aliran atau pandangan politik pada masa pra kemerdekaan. Pembentukan partai politik setelah Indonesia merdeka kerap didasarkan pada nilai atau prinsip ketuhanan, kebangsaan, dan marxisme. Meskipun demikian, hal ini tidak lantas menghalangi kemunculan partai-partai yang lahir dengan berlandaskan nilai atau prinsip lainnya.

\section{DAFTAR PUSTAKA}

Afifah, Wakhidatul, Implementasi Fungsi Partai Politik, Mustika Cemerlang, Semarang, 2011.

Asep Mulyana, https://referensi.elsam.or.id/2015/01/perkembangan-pemikiran$\underline{\text { ham/. }}$.

Budiardjo, Miriam. Dasar-dasar Ilmu Politik, Gramedia Pustaka Utama, Jakarta, 2007.

Findarost Yufan Madakarah, dkk., "Perkembangan Pengaturan Pembubaran Partai Politik dalam Sistem Ketatanegaraan Republik Indonesia”, Diponegoro Law Journal, Vol. 6. No. 2. (April 2017), pg. 1-13. 
Penetapan Presiden Republik Indonesia Nomor 7 tahun 1959 tentang Syarat-Syarat dan Penyederhanaan Kepartaian.

Peraturan Presiden Republik Indonesia Nomor 13 Tahun 1960 tentang Pengakuan, Pengawasan dan Pembubaran Partai-Partai.

Penetapan Presiden Republik Indonesia Nomor 7 tahun 1959 tentang Syarat-Syarat dan Penyederhanaan Kepartaian.

Warsito, Tulus. Pembangunan Politik Refleksi Kritis atas Krisis, Bigraf Publishing, Yogyakarta, 1999. 